\title{
Effect of Prolonged Heating at High Temperature on the Hardenability of Boron-Treated Steels
}

\author{
by R. M. Goldhoff, R. Speiser and J. W. Spretnak
}

$\mathbf{I}_{\mathrm{t}}^{\mathrm{T}}$ $T$ has been observed by Grange and Garvey ${ }^{1}$ that 1 the homogenization of boron-treated steels could lead to complete elimination of the hardenability effect caused by boron. The experimental conditions leading to this conclusion involved the heating of steel specimens with and without boron at $2350^{\circ} \mathrm{F}$ for $24 \mathrm{hr}$. To prevent oxidation and decarburization, the specimens were encapsulated under vacuum in silica tubes. This observation of permanent deterioration of boron effect was noted in both a 0.63 pct plain carbon steel and a 0.25 pct $C$ low alloy steel, both of which had been treated with ferroboron and homogenized at $2350^{\circ} \mathrm{F}$ for $24 \mathrm{hr}$. In another series of boron-treated steels which had been homogenized for shorter times, the effect was to reduce, but not completely eliminate, the boron effect. Under these circumstances, it was presumed that longer heating times would cause permanent deterioration of the boron effect in this series of steels also. Since the characteristic grain boundary constituent could not be formed in any of these steels after homogenization, it was concluded that possibly boron was being

Table I. Analysis of Republic Steel Corp. Heat E-38720*

\begin{tabular}{|c|c|c|c|c|c|c|c|c|c|}
\hline & $\mathbf{C}$ & Mn & $\mathbf{P}$ & $\mathbf{s}$ & $\mathbf{S i}$ & $\mathbf{N i}$ & $\mathbf{C r}$ & Mo & B \\
\hline $\begin{array}{l}\text { E-38720 } \\
\text { ladle }\end{array}$ & 0.39 & 0.85 & 0.015 & 0.019 & 0.31 & 0.53 & 0.48 & 0.23 & - \\
\hline $\begin{array}{l}\text { 3A } \\
\text { Grainal } \\
\text { No. } 79 \div\end{array}$ & 0.395 & 0.89 & - & - & 0.31 & 0.54 & 0.48 & 0.25 & 0.0013 \\
\hline $\begin{array}{l}5 A \\
\text { base }\end{array}$ & 0.396 & 0.88 & - & - & 0.31 & 0.54 & 0.47 & 0.25 & 0.0000 \\
\hline
\end{tabular}
${ }^{*}$ Heat had base analysis of 8640 ; special ingot treated with
Grainal No. 79. 5A represents base analysis; $3 \mathrm{~A}$ represents base plus Grainal No. 79. 5A represents base analysis; $3 \mathrm{~A}$ represents base plus four $1 \mathrm{~b}$ per ton of Grainal No. 79

$\uparrow$ The manufacturers of Grainal No. 79 list the nominal composi, 13 pet $\mathrm{Al}, 4$ pet $\mathrm{Zr}, 8$ pet $\mathrm{Mn}, 5$ pet $\mathrm{Si}$, 0.50 pet $B$, and remainder iron.

converted into an ineffective form through chemical combination resulting from prolonged heating at high temperatures. Assuming the validity of this observation, a series of experiments to establish the relationship between temperature of homogenization and kinetics of deterioration was contemplated.

Initially an attempt was made to reproduce the results just described. For this purpose commercial lots of AISI 8640 and AISI 86B40 steels were used. The analyses of these steels appear in Table I. Hardenability evaluation was on the basis of the hardness of normalized sections. Grange and Garvey ${ }^{1}$ pointed out that these steels are air hardening to some extent and such a technique can be used. For these tests the specimens were held for $20 \mathrm{~min}$ in a salt bath at $1600^{\circ} \mathrm{F}$ and then cooled in still air.

Several evacuated silica capsules containing pairs of the test steels were made up and heated for 24 $\mathrm{hr}$ at $2350^{\circ} \mathrm{F}$. A number of failures occurred among

R. M. GOLDHOFF, formerly Graduate Student, Dept. of Metallurgical Engineering, Ohio State University, is now Metallurgist, Large Steam Turbine-Generator Dept., General Electric Co., Schenectady. R. SPEISER, Associate Member AIME, and J. W. SPRETNAK, Member AIME, are Associate Professors, Dept. of Metallurgical Engineering, Ohio State University, Columbus, Ohio.

TN 351E. Manuscript, Oct. 13, 1955. these capsules, but evaluation of the specimens successfully treated indicated a complete deterioration of the boron effect. However, examination of the surface of the treated specimens showed that some reaction, probably with the silica tube, had taken place, since none of the specimens was bright. One further test was made at $2350^{\circ} \mathrm{F}$ for $12 \mathrm{hr}$, using a pair of specimens wrapped in tantalum foil prior to encapsulation. These specimens appeared bright after treatment, and their hardenability evaluation showed that no deterioration had taken place.

Since these steels are extremely sensitive to deboronization at high temperatures and particularly at long times of holding, the experimental observations raised some doubt as to the real occurrence of the permanent deterioration effect. To resolve this question an experiment was undertaken in which the high temperature portion of the treatment was completed in vacuum. For this purpose a molybdenum wound resistance furnace capable of maintaining good vacuum was used. All the pertinent accessories to this furnace were machined from molybdenum stock in order to withstand the high temperature involved in the experiment. With this equipment a temperature of $2400^{\circ} \mathrm{F}$ was obtained and held under a pressure of $5 \times 10^{-5} \mathrm{~mm} \mathrm{Hg}$ for 24 hr. A specimen of each of the two test steels was suspended in the furnace and both were heated simultaneously. Temperature was measured with a standardized $\mathrm{Pt}-\mathrm{Pt}-13$ pct $\mathrm{Rh}$ thermocouple, whose millivoltage at $2400^{\circ} \mathrm{F}$ was extrapolated from the standardization equation, good up to $2200^{\circ} \mathrm{F}$.

The complete evaluation of these specimens is shown in Table II. The hardness values attained by each steel after normalizing, both before and after the prolonged high temperature treatment, remain the same. A microscopic study of the decomposition products present in the microstructures of specimens

Table II. Hardenability Evaluation of Commercial AISI 8640 and AISI 86B40 Steels Before and After Prolonged Heating

\begin{tabular}{lcc}
\hline & \multicolumn{2}{c}{ Hardness Values, Rc } \\
\cline { 2 - 3 } Heat Treatment & AISI 86B40 & AISI 8640 \\
\hline As-received & 25 & 25 \\
20 min at $1600^{\circ} \mathrm{F}$, air cool & 48 & 28 \\
24 hr at $2400^{\circ} \mathrm{F}$, min at $1600^{\circ} \mathrm{F}$, air cool & 47 & 28 \\
\hline
\end{tabular}

at various points in the heat treatment correlated with the hardness values observed.

It seems that no permanent loss of boron hardenability effect occurs, at least in these Grainal-treated steels, when deboronization is circumvented.

\section{Acknowledgments}

This work was conducted under the sponsorship of the Aeronautical Research Laboratory, Wright Air Development Center, under Contract No. AF 18(600)-94, and their support and permission to publish is gratefully acknowledged. A note of thanks is also extended to the Republic Steel Corp. for supplying the materials used in the work.

\section{References}

1 R. A Grange and T. M. Garvey: Factors Affecting the Hardenability of Bronge and T. M. Garvey: Factors Affecting the Harded Steels. Trans. ASM, 1946, vol. 37, p. 136 . 